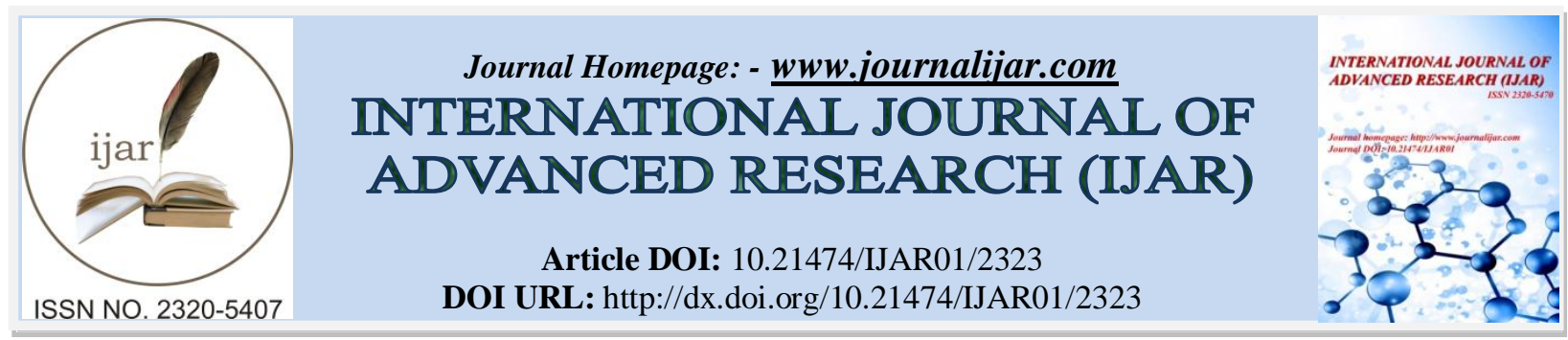

RESEARCH ARTICLE

\title{
THE DEVELOPMENT OF POTENTIAL CREATIVE ECONOMY BASED ON LOCAL WISDOM IN DEALING WITH GLOBAL CHALLENGES.
}

Nur Ida Iriani, Warter Agustim and Totok Sasongko.

Faculty of Economy, University of Tribuwana Tungga Dewi.

\section{Manuscript Info}

Manuscript History

Received: 30 September 2016

Final Accepted: 30 October 2016

Published: November 2016

Key words:-

Creative Economy; Local wisdom

\begin{abstract}
The aim of this study is to describe the potential sector of creative economy in Sumberopasir village of Malang, Indonesia. The results of this study showed that the industrial centers of embroidery Sumberpasir Village suffered a setback in the context of production and craftsmen. Many factors led to the deterioration and it takes the right strategy to drive growth in the embroidery industry by analyzing the strength and weakness of internal factors and opportunities and threats of external. The solutions that can be done to develop the industrial center of embroidery are to harness the power of internal and external opportunities to gain a wider market and cover the internal weaknesses and avoid external threats.
\end{abstract}

Copy Right, IJAR, 2016,. All rights reserved.

\section{Introduction:-}

Right after the end of 2015, Indonesia will welcome the implementation of the free market of Southeast Asia, or commonly referred to the ASEAN Economic Community (AEC). Indonesia is expected to get benefit from the implementation of this MEA because of three reasons. First, the implementation of the MEA potentially makes Indonesia as a supplier of energy and raw materials for industry within ASEAN region due to the benefits derived from natural resource resources. Second, the implementation of MEA expands the Indonesia's market since the implementation of single market that open the flow of goods, services, investment, and skilled labor force. Third, the implementation of the AEC will encourage the inflow of investment into Indonesia from within and outside ASEAN.

The existence of the creative economy has a great potential to become one of the driving sectors to capture the opportunities in MEA. Creative economy continues to grow as the development of technological information which establishes a new form of creativity in the form of creative industries based on local wisdom and science. Creative economy is not only about the creation of economic value added, but also the creation of value added in the social, cultural, and environmental. The creative industries which are a subsystem of the creative economy become the driving force in creating those values. The natural, cultural, and human resources in Indonesia can produce a great potential when it combined with human creativity so that it can contribute not only to the national economy, but also in strengthening image and identity of the nation as well as the development of renewable resources and innovation. By the implementation MEA and the progress of technological information, creative economic will continue to grow and establish a new form of creativity. Nowadays creative industries do not only produce art and cultural products, but also produce daily life products. The growth of creative industries in all countries is greater than the average growth of the global economy, including its contribution to job creation, value added, and the amount of businesses. In addition, the exports of the world's most creative product continued to rise (UNCTAD, 2013).

Corresponding Author:- Nur Ida Iriani.

Address:- Faculty of Economy, University of Tribuwana Tungga Dewi. 
Creative economy in Indonesia also substantially contributes to the national economy. Based on the calculation of the Central Bureau of Statistics, during the period 2010-2013 the creative economy contributes $7.8 \%$ of the Indonesia's GDP. The contribution of creative economy is relatively lower than the contribution of agricultural, industrial processing, trade, and restaurants or the service sector, but much higher than mining, quarrying, finance, and transportation sector. The added value generated by the creative economy is also increasing every year. Based on the calculation of Central Bureau of Statistics, the value added of the creative economy was reaching Rp 641.8 trillion in 2013 with growth around 5.76\%, higher than the growth in the sector of electricity, gas,; mining and excavation; agriculture, livestock, forestry, and fisheries; services; and industrial processing. In addition, in 2013, the number of creative industries totaled 5.4 million businessman absorbed 11.8 million labor forces. The growth of employment in the creative industry in 2013 amounted to $0.63 \%$, higher than the average national employment growth which experienced a slowdown of $0.01 \%$ in the same year.

Gross Domestic Product of creative economy is mostly contributed from the subsector of culinary (32.5\%), fashion (28.3\%), crafts (14.4\%), and publishing and printing (8.11\%). In 2013, the number of creative industries totaled 5.4 million businessman absorbed 11.8 labor forces. $90 \%$ of job field creation is contributed by three sectors they are mode $(32,33 \%)$, culinary $(31,48 \%)$, and art $(26,2 \%)$, while the rest is coming from another 12 sectors. The growth of creative industry business stood at $9.68 \%$. The subsector of creative economy which grew above-average of the national business growth $(0.9 \%)$ is the performing arts $(3.18 \%)$, research and development $(2,98 \%)$, interactive games $(2.87 \%)$, advertising (2.86\%), film, video and photography (2.74\%), music (2.4\%), and technological information $(2.15 \%)$.

The competitiveness of Indonesia's creative industries can be identified into seven main dimensions, namely: creative resources, support resources, industry, finance, marketing, infrastructure and technology, as well as institutional. Based on the seven dimensions mapping, an average of the competitiveness of 15 sub-sectors are still relatively low. The financial problem was difficult to be fulfilled by the creative sector players, especially those who are beginners. In facing the global market creative industries require strong competitiveness so that it can continue to grow.

Studies conducted by Sholeh (2013), shows that Indonesian government should move faster to address the AEC. In addition lack of socialization about the AEC and its development towards the wider community is also one thing that is crucial for the Indonesian government. Based on Ivan Liang Chen Sui (2013), in the last fifteen years Indonesia has become the target market for creative products derived from the creative industries. Therefore, it takes strategy and regulation to develop the creative industries in Indonesia in order to penetrate the global market. While J.W. Saputro et al, (2010) stated that to expand market share and improve the competitiveness of SMEs requires an application that can integrate and automate the business processes. The lack of Indonesia's economic competitiveness is caused by many factors, both internal and external small businesses. Therefore, an identification of the causal factors of low competitiveness of small businesses to find the next model in improving the competitiveness of small businesses is essential and urgent in conditions of free market competition (Rifai, 2013).

The existence of MEA was initiated by ASEAN Summit (KTT) in December 1997 in Kuala Lumpur Malaysia. Then continues in October 2003 during a summit in Bali, Indonesia, which resulted in the establishment of MEA 2015. The establishment of MEA makes each ASEAN member country freely to export and import the goods and services. Each ASEAN member countries will accept guests from a variety of ethnic, racial, cultural, and religious more than ever before, especially tourists from the region ASEAN. Although cultures in Southeast Asia are the same to one another ASEAN countries, but there are cultural differences that cannot be blend which contains an element of local wisdom. So it opens the possibility remains of the dissemination, mixing, or even cultural assimilation.

\section{Literature Review:-}

\section{The Development of Creative Economy:-}

Creative industry is defined as industry focuses on the creation and exploitation of intellectual property such as works of art, film and television, software, games, or fashion design, and creative services including inter-company such as advertising, publishing, and design. The term creative industry is another term of the cultural industry. The term was first used in the early 1990s in Australia, but developed rapidly by the British government in the late 1990s. The British government specifically formed unit and coordinator of creative industries under the Ministry of Culture, Media and Sport (Primorac, 2006). Many definitions of creative industry, one widely quoted definition is an industry that has authenticity in individual creativity, skill and talent that has the potential in bringing a revenue and 
job creation through the exploitation of intellectual property. Meanwhile, according to the United Nations Conference on Trade and Development (UNCTAD), the creative industries are (UNCTAD, 2008): (1) cycle of creation, production, and distribution of goods and services that use creativity and intellectual capital as primary inputs; (2) Part of a series of knowledge-based activities, focusing on art, which could potentially generate revenue from trade and intellectual property rights; (3) Consists of products that can be touched and intellectual who cannot be touched or services to the charge of creative artistic, economic value and market objectives; Multispectral between art, services, and industry; and (4) Part of a new dynamic sectors in world trade. Creative economy is part of a system of contemporary economics. So the creative economy is about a very wide spectrum, namely all aspects which aims to improve competitiveness by using individual creativity viewed from economy perspective. The creative industries are a part of the creative economy and focus on their respective industries.

In Indonesia, the creative industry is defined as industry derived from the use of creativity, skill and talent of individuals to create wealth and jobs by generating and exploiting the creativity and inventiveness of the individual. The development of creative economy is consist of foundation, 5 (five) pillars, and roof as follows:

a) Foundations: People (Human Resources), the main asset of the creative industries that characterize almost all sub-sectors of the creative industries;

b) Five Main Pillars that have to be strengthened in developing creative industries they are: (1) Industry is a collection of companies engaged in the field of creative industries; (2) Technology is an enabler to realize individual creativity in the form of real work; (3) Resources is input required in the creative process, eg natural resources, land; (4) Institution is the social order (norms, values, and laws) that govern the interactions between economic agents, especially in the field of creative industries; and (5) Financial Intermediary institution.

c) Roof: building the creative economy is housed by the triple helix interaction composed of Intellectuals (IPR), Business (Business), and Government (the Government) as the main actors driving the creative industry. (1) Intellectual, intellectuals who were in formal educational institutions, non-formal, and informal have a role as driver of the science and ideas creation which is a source of creativity and the invention of the creative potentials of Indonesian people. (2) Business, entrepreneurs are able to transform creativity into economic value, (3) Government, the government as a facilitator and regulator so that creative industries can grow and thrive.

\section{Entrepreneurship:-}

Entrepreneurship is derived from the French language, which means doing something without economic connotation (Paula, 1996). According to Stoner, Freeman and Gilbert (1996) entrepreneurship is defined as the ability to take the factors of production (land, labor, and capital) and use it to produce goods or services. Furthermore, entrepreneurs understood in more complex meaning and concepts. In contrast, Schumpeter emphasized more on the concept of innovation, where entrepreneurs combine resources in innovative ways to produce something new. An entrepreneur make decisions based on intuition and not based on the past experience. The role of the entrepreneur is mated creative ideas with measures aimed and structured from and for business purposes. So successful entrepreneur can be measured by its ability to complete the process of creativity, then generate innovation, until the application can be deployed and get into the markets (local, regional and international) with a certain profit level (Kompas, 2000: 45). Some understanding and definitions described above provides an overview of an entrepreneur. So entrepreneurs here is defined as individuals who are always trying to process existing resources in a certain way in order to look for business opportunities, although risky to get a certain profit level.

\section{Methodology:-}

This study was conducted at the center of economic enterprises of embroidery in the Sumberpasir village Pakis, Malang. The intake of this research location determined by purposive with consideration; (1) the industry is laborintensive deployed to produce embroidery quality. (2) the market of the industry of is domestic and overseas markets, and (3) a center of creative economy industry is a mainstay of the local government district Malang. The populations in this study are businesses in the center of the creative industry embroidery, which amounted to 37 businesses embroidery. Determination method of sample by purposive sampling with certain criteria; (1) Recorded in the service industry and local commerce; (2) get the management development from its related institutions; (3) Having a business at least 10 years; and (4) It has at least 5 workforce. The number of samples in this research is determined by using a census approach. In addition, respondents also involve in relevant government agencies ranging from the village, sub-district, and district offices of Malang. Data was collected from observation, interview, and documentation. Data collected will be presented and examined by the descriptive method. Additionally in this 
study also used a SWOT analysis. The result of this study was carried out in detail towards the results of data analysis that has been done, then proceed to the conclusion of the study.

\section{Result and Discussion:-}

The potential of the creative economy in the industrial centers of embroidery in the Sumberpasirvillage is very large. By combining elements of local wisdom, creativity, and value-added is a key word that encourages innovation in sectors of the economy that developed in the local community. Local wisdom is a geographical advantage which will characterize the real difference between one area to another. The difference gives a distinguishing feature; one of them is potential in the field of creative economy. Economy based on local wisdom can be the solution to retain, preserve and cultivate the culture and local products to face MEA. Creative Economy based on local wisdom is the combination of two elements, namely the creative economy and local culture. Creative economy means a concept in a new economic era that intensifies information and creativity by relying on the ideas and knowledge of human resources as the main factor of production.

A creative economy product which is looking at the potential of local knowledge, that promising, creates the added value. Added value, that serves as a conduit value added to a product,make the product that actually has been prevalent transform into a product that worth more than similar productand create the double value of a product. The developmentof creative economy is inseparable from the development of the local culture so that the more creative a packed cultural society, then the country will have stronger identity and image that encourages economic growth. One of the key factors to develop the creative economy is how an applied area as a center of culture and art (Howkins, 2009). City or region is defined as a creative-based creativity as a way of life in three main aspects: economy (creative economy), social (creative society), and government (creative policy).

Interaction and collaboration of the main actors of creative economy are based on the strong foundation, supported by sturdy pillars, as well as the institutional that support the development of creative economy will produce a strong institutional creative economy based on the characteristics and identity of a region. The creation of creative products based on local wisdom often goes up because of the absence of an entity that drives the process of coordination and synergy in a systematic and weak leadership that can mobilize all stakeholders. In order to be achieved, planning, implementation, and evaluation are a process that needs to be done to run continuously. So the future businesses for creative economy are a sector which increases the added value of export of Indonesian products in the local and global market. Local wisdomis values of local communities that formed naturally and obtained through the learning process of time to time. So creative economy based on local wisdom is the creative economy that makes the local culture as a source of ideas, inspiration, and innovation as well as a development base, Creative economy emerged is in line with the potential resources available in the local area.

Local wisdom is chosen as the basis of creative economic development because it is considered in compliance with the characteristics as a creative economy, namely; based on the idea that culture is the result of work, initiative, and a sense of human. Creative economy is an economy that makes creativity, culture, heritage, and the environment as the foundation of the future. This means that culture is something that cannot be separated and became one of the legitimate requirements in creating a product of the creative economy. Todays in parts of Indonesia, including the Sumberpasirvillage of Malang has great potential in applying creative economy based on local wisdom, seeing diversity culture and raw materials possessed this region has its own uniqueness. As we know that Indonesia has the local culture that are scattered throughout the provinces. The diversity of local cultures needs to be respected, removed, and manifested into a creative economy program. Based on data from the Ministry of Tourism and Creative Economy, the creative economy has accounted for the economic growth of $7 \%$ to the national GDP from 2012 to 2013. The highest added value is sub-sector of fashion, culinary, crafts, publishing and printing. The fourth sub-sector is closely linked to the tourism sector, which means the main source of culture.

Currently there are fourteen sub-sectors of the creative economy based on mapping conducted by the department of trade of the Republic of Indonesia namely: advertising, architecture, art market, crafts, design, fashion, culinary, video, film, photography, interactive games, music, performing arts, publishing and printing, computer services and software, television and radio, as well as research and development. All of the fourteen sub-sectors, creative economy based on local wisdom can be developed in all subsectors. As examples are embroidery and batik clothing. Batik is an art picture on cloth for clothing material that has long been known since the development of the kingdom in the archipelago. Batik initially worked only limited in the palace and the result is only to be used by the king, his family and his followers. At that time batik written and painted on palm leaves. The pattern is still dominated by the 
shape of animals and plants. The history of its development, batik has undergone many changes, from the motif, color, and shape up to the embroidery creations. Batik which was only used by the royal family, is now a popular folk clothes, which can be used by anyone, anytime, and anywhere both women and men, both young and old. Thus batik can be known, recognized, respected, and loved, especially by Indonesia itself. It proves that every local wisdom in Indonesia have the same opportunities to grow and develop into better through creative economic development of local culture-based creativity as long as it remains keep the original values contained therein.

Creative economy based on local wisdom will preserve and prevent the exploitation of culture itself, which is expected to realize the durability which is implemented through a philosophy of life, knowledge, and strategies of life in the form of activities undertaken by local communities to address the various problems in the fulfillment of their needs. The aim is to maintain the essential values of local wisdom which has been largely abandoned as the value of mutual cooperation, brotherhood, tolerance, ethics and morals. This is considered important because local knowledge is seen as a national identity that serves as a philosophy and way of life that manifests in various fields of life. To achieve the aim it requires good quality human resources so that the results are is high quality of competitiveness. Since the key to success in the creative economy lies in human resources as the main production factor. Therefore all factors that support the improvement of the quality of human resources such as education and health must be increased.

As technological embroidery industry advances, Sumberpasir village is currently experiencing a lot of problems. It takes the concern of government where the current government is mobilizing forces to stimulate the growth and development of creative industries in Indonesia but Activists or embroidery artisans start to diminish. Some of the obstacles related to the development of creative economy include:

1. The development of creative industries is not optimal due to the lack of attractiveness of the industry, the dominant position of creative endeavor, the creative industry business model is not yet mature, as well as the business risk that must be faced.

2. Development of content, creation, and creative technology is not optimal due to inadequate Internet infrastructure, infrastructure building performance do not meet the standards, high production machine, the high cost software product and creative services, lack of research content, and lack of activity content archiving.

3. Lack of expansion and market penetration for products and creative caused by a lack of appreciation of local creativity, lack of connectivity distribution, concentrated global markets, the high cost of promotion, no online payment, and lack of monitoring of the royalties, licenses, copyrights.

4. Weak institutions of creative industries due to the absence of legal framework regulating the governance of their respective sub-sectors; the business climate is not conducive, the appreciation of the low and high piracy, and electronic transactions has not been well regulated.

5. The lack of access to financing creative economy sector due to the lack of financial scheme with the characteristics of the creative industries are generally not bankable, high risk high return, fluctuating cash flow, as well as intangible assets.

6. Development of creative economic resources is not optimal, the problem of scarcity of raw materials, lack of raw materials research, the gap between education and industry, as well as standardization and certification are not good.

Since 2009, Indonesia's creative economy development model using triple-helix, which requires a synergy and partnership between the three main actors: the government, private, and intellectual (a team of experts from academia and the public). However, the trend is now showing the active participation of the creative community in various regions. Responding to these developments, the quad-helix collaboration among government, private, intellectual, and creative community is more appropriate to apply. The model of creative economic built by the quad-helix, the foundation are creative people and is supported by five main pillars, ie resources, industry, distribution finance, marketing, technology and infrastructure. Between the foundation and pillars cannot interact effectively if there is no institutional support as the roof of the development model of the creative economy. The pillars are housed within institutions to support the development of creative economy.

In the future, both central and local governments should establish a conducive institutional and prioritize the creativity through an increasing of creative cities. With an effective institutional, each local government would easily apply creative city development policies based innovation by strengthening educational institutions, facilitating the novice entrepreneurs, providing access to financing and the availability of infrastructure, and regulatory support. 


\section{Conclusion:-}

In facing the global market-based on creative economy local wisdom is expected to become the main drivers for the Indonesian nation to acquire wealth and prosperity without having to leave or forget the wealth of local potential. Since local culture is created not to bring disaster but for survival of asustainable local communities in accordance with the environment, customs, values and norms. Yet creative industries still experienced many obstacles, such as:

a) the development of creative industries is not optimal due to the lack of attractiveness of the industry, the dominant position of creative endeavor, the creative industry business model is not yet mature, as well as the business risk that must be faced.

b) Content development, creation, and creative technology are not optimal due to inadequate internet infrastructure, building infrastructure performance do not meet the standards, high production machine, the high cost of software-producing, the lack of research content, and lack of activity content archiving.

c) Lack of expansion and market penetration for products and creative services at home and abroad caused by a lack of appreciation of local creativity, lack of connectivity distribution, concentrated overseas markets, the high cost of promotion, do not implement online payment systems, and the lack of monitoring of royalties, licenses, copyrights.

d) Weak institutions of creative industries due to the absence of legal framework regulating the governance of their respective sub-sectors; the business climate is not conducive, the appreciation of the low and high piracy, and electronic transactions has not been well regulated;

e) Lack of access to financing creative economy sector due to the lack of financial scheme with the characteristics of the creative industries are generally not bankable, high risk high return, cash flow fluctuating, as well as the assets are intangible ; and creative development of economic resources is not optimal, the problem of scarcity of raw materials, the gap between education and industry, as well as standardization and certification are not good.

\section{Reference:-}

1. Adam Jerusalem, Muhammad. 2009. Perancangan Industri Kreatif Bidang Fashion dengan Pendekatan Benchmarking pada Queensland's Creative Industri http://eprints.uny.ac.id/5112/1/Benchmar king.pdf (pada Tuesday, Desember 02,2014, 4:44:42 PM

2. Departement Perdagangan RI. 2007. Industri Kreatif Indonesia DepDag RI. http://industrikreatifdepdag. blogspot.com/2007/10/studi-mappingindustri- kreatif.html (2 Desember 2014 :04:33)

3. Gibbons et al. 1994. The New Production of Knowledge, Ministry of Economy, Trade and Industri, Januari

4. Gunaryo, Ernawati, Sudarman D. 2008. Pengembangan Industri Kreatif Indonesia 2025. Departemen Perdagangan RI. http://dgi-indonesia.com/wp-kontent/uploads/2009/05/buku-I-rencana pengembangan ekonomi kreatif indonesia-2009. Pdf pada 2 desember 2014

5. Ivan Chen Sui Liang. 2013. Industri Kreatifdan Ekonomi Sosial di Indonesia: Permasalahandan Usulan Solusidalam Menghadapi Tantangan Global, Prosiding The 5th International Conference on Indonesian Studies; Ethnicity and Globalization.

6. J.W. Saputro, Putu Wuri Handayani, Achmad Nizar Hidayanto, danIndra Budi, 2010, Peta Rencana (Roadmap) Riset Enterprise Resource Planning (ERP) denganfo kusriset pada Usaha Kecil dan Menengah (UKM) DiIndonesia. Journal of Information Systems, Volume 6,Issues 2,October2010

7. Kotler, Philip. 1997, Manajemen Pemasaran, Analisis, Perencanaan, Implikasi dan Kontrol, Jilid I, Edisi Revisi, Terjemahan Hendra Teguh dan Ronny Antonius Rusli, PT. Prenhalindo, Jakarta

8. Lemhanas RI. 2012. Pengembangan Ekonomi Kreatif. http://www. lemhanas.go.id /portal/images/stories/humas/jurnal/edisi_14-Desember 2012 I Ekonomi.pdf.

9. Jawa Pos, MEA Dorong Transaksi Dagang, Jawa Pos, 11 Nopember 2014 hal. 6.

10. Paula, Kyro,. 1996. The Points of Transition In Reforming The Understandingand Meaning of Entrpreneurship, Academy of Entrepreneurship Journal, European Edition, Volume 2, Number 1

11. Pusparini \& Siti Czafrani. 2010. Pengembangan Ekonomi Kreatif Berbasis Kearifan Lokal Oleh Pemuda Dalam Rangka Menjawab Tantangan Ekonomi Global.

12. Oslon, dan Peter. 2000. Consumer Behavior, Prilaku Konsumen dan Strategi Pemasaran, Jilid I, Edisi 4, Cetakan 1, Terjemahan Damos Sihombing, Erlangga : Jakarta

13. Rifai. M; B. Prihatminingtys; RY Susanto; Wani HU, 2013, Peningkatan Daya Saing Dalam Mendorong Pengembangan Industri Makanan dan Minuman Berbasis Kerakyatan Menuju Good Local Industry, Laporan Penelitian MP3EI, DP2M Dikti 2013.

14. Satria, Dias \& Prameswari Ayu. 2008. Strategi Pengembangan Industri Kreatif Untuk Meningkatkan Daya Saing Pelaku Ekonomi Lokal. 
15. Sholeh, 2013, Persiapan Indonesia DalamMenghadapi AEC (Asean Economic Community) 2015, e-Journal Ilmu Hubungan Internasional, Volume 1, Nomor 2, 2013: 509 - 522

16. Stoner, James A. F.; Freeman, R. Edward \& Gilbert JR, Daniel R., (1996), Manajemen Jilid I, Jakarta, PT. Prenhallindo. 